\title{
The Tide that Failed to Rise: Young People's Politics and Social Values in and after the Arab Uprisings
}

Pamela Abbott p.abbott@abdn.ac.uk University of Aberdeen School of Education

Andrea Teti a.teti@abdn.ac.uk University of Aberdeen School of Social Sciences

Roger Sapsford rjsapsford@gmail.com University of Aberdeen School of Social Sciences Corresponding author

23-31 Commercial Rd, Insch, Aberdeen AB52 6JN

\section{ACKNOWLEDGEMENTS}

The Arab Transformations Project is an international research project operating within the European Commission's FP7 framework, Grant No. 320214. The authors acknowledge the contribution of the partners to the project and specifically the design and conduct of the Arab Transformations survey on which this paper draws.

The authors alone remain responsible for the content of this Article; it does not necessarily represent the views of the EU, the Court of the University of Aberdeen or any of the project partners.

\begin{abstract}
The story of the 'Arab Spring' as a revolt of young people against autocracy does not stand up to survey analysis at country level. Data from the Arab Transformations Survey show that young people were over-represented as participants, but it is necessary to stretch the concept of 'youth' into middle age in some countries to say this, there were plenty of older participants, and the protests were aimed less at political rights and more at social justice. Fundamental political changes have been expected in MENA which would sweep away autocratic rule in favour of democratisation, as the values successive younger generations became individualised, liberalised and secularised under the influence of economic and market development and the spread of education, but there is very little evidence that this is what occurred in the Arab Uprisings. Whether young or older, protestors were looking for regime change, an end to corruption and a reduction in IMF-inspired austerity, but political freedoms and democratic governance do not appear to have been at the top of their agenda.
\end{abstract}

\section{KEYWORDS}

MENA, Arab Uprisings, Youth, Modernisation Theory, Secularisation, Gender attitudes 


\section{INTRODUCTION AND BACKGROUND}

The Arab Uprisings in the MENA region in and around 2011 took everyone by surprise - scholars, the press, international powers and even the MENA rulers themselves (Gause 2011). The death in Tunisia of Mohamed Bouzizi, who set himself on fire at the end of 2010, sparked off 29 days of sustained protests in that country which in turn led to regime change when President Ben Ali fled the country. The fire swept across the Arab world; there were protests in Jordan, Oman and Egypt starting in January 2011, followed by uprisings in Yemen, Bahrain, Libya, Iraq, Morocco and Syria (though the uprising in Iraq should probably be seen as an extension of existing conflict, the protests in Libya quickly became an armed civil war with external support and Syria and Yemen also faced ongoing civil wars).

The dominant 'story' told by the press, the television and some of the contemporaneous research (e.g. Howard and Hussein 2011, Wilson and Dunn 2011) characterises the Uprisings as youth revolutions. It is a story of young people, linked by and organized through the online 'social media', who took to the streets in opposition to the politics and practices of oppressive regimes. Media accounts variously presented young people in political revolution frustrated with the governance of their countries or else young people with economic grievances and a lack of economic opportunity (see Esposito 2011; Gardiner 2011; Knickmeyer 2011; Shenker et al 2011), but it was the political rather than the economic picture that captured the world's imagination.

In this article we explore the part played by young people in the Arab Uprisings, their values and their political aspirations. Qualitative research provides considerable insights into the lives and conceptual frameworks of those with whom it is carried out, but by its very nature it is not reliable tool for estimating frequencies and correlations in the population as a whole; for that purpose, surveys are more useful. The data on which our analyses are based come from a representative sample drawn in each of six countries - the Arab Transformations Survey carried out in 2014 in MENA countries across North Africa and the Middle East to the East of the Mediterranean. In our review of literature we also draw on similar surveys carried out periodically which include these countries: the Arab Barometer (AB) and the World Values Survey (WVS). The article considers why age matters for political theory in this area, the age-groups most likely to participate or support the Uprisings and the size of their contribution to the total participant group in a country, the extent to which age-groups differed in their political values and the nature of their political and economic goals. It concludes that young people were disproportionately likely to have participated but they those aged less than 35 formed half or less of the participants in most countries and the peak ages for participation vary to some extent by country. Overall, young people were important for the Uprisings but it would be a mistake to characterise them as dominated by young users of the internet and social media, as was suggested at the time.

\section{The democratisation of developing countries}

The process of development and economic transition has been associated across the world with a growth in democracy. The theory is that economic benefits of development mean that a growing proportion of the population no longer has to worry exclusively about survival needs. Lipset (1959, 
1994) listed conditions which were prerequisite or co-requisite for the establishment of a sustainable democratic form of governance:

- (economic and demographic transition): economic development, industrialisation, urbanization, the growth of a middle class;

- (socioeconomic mechanisms): extended educational provision, greater equality and the inclusion of all workers within the bounds of citizenship (and while Lipset does not explicitly discuss gender, avoiding the exclusion of more than half the population by treating women as full and equal citizens is a fairly obvious extension of the principle).

In this view, economic growth, urbanization, education and literacy necessarily lead individuals to interact in more complex ways and so to develop liberal attitudes and secular views which are expressed in their political participation. The growth of civil society organisations such as trade un ions, which develkop and exercise a politica critique, is also a part of industrialization. Since most Arab countries have now industrialized, modernisation theory expected that Arab states would democratize or at least display evidence of pressure for democracy. The 'democratic deficit' in Arab countries was therefore something of a puzzle, particularly as many such countries show strong rhetorical support for democracy in the abstract.

One development of the theory has been a growing emphasis on value change, as well as economic transition, as precursor to or co-requisite for political liberalisation. Economic and then social development was expected to lead to a milieu driven more by ability and effort than custom and connections, leading to a greater emphasis on individual rights. Modernisation moves societies from traditional to secular rational values - 'the rules' become seen as social products to be discussed and sometimes changed rather than fixed by tradition or religious fiat. People develop the will to be heard and to have some impact on decisions, and civil society is there to support these wishes. Authoritarian regimes therefore experience growing mass pressure to democratize and liberalize, to the point where it begins to elude the regime's grasp (Issawi 1956, Lerner 1958, Inglehart and Baker 2000, Inglehart 2017).

The Uprisings could be seen as a change-point or at least a sign of readiness. While demonstrators did not prioritize procedural democracy and political freedoms in their demands, these were political in the sense of demanding responsive government and the replacement of incumbent regimes with ones that would listen to citizens (Teti et al 2018). Working on successive rounds of the Arab Barometer, Tessler and his colleagues (e.g. Tessler 2015) demonstrated strong and growing surface support for democracy. However, as has been argued for quite some while (e.g., Almond and Verba 1959), abstract proclamations of approval or support are not enough and what is needed is an examination of the attitudinal base required to support and sustain democratic forms of government. In broad terms, these are evidence-based public rationality, inclusive and emancipatory characterisation of all groups in the population and detachment from the rule of religion in political matters (secularisation) - see also Moaddel and de Jong (2017). Attention is also focussing more broadly on underlying norms or expectations for how others should and will behave and social processes of cohesion and inclusion (see Abbott et al 2016, author reference). 


\section{Authoritarian resilience and cultural closure}

The value-changes which accompanied developmental industrialisation and commercialisation elsewhere across the world appeared to be passing the MENA region by, and some of the explanation for this 'democratic deficit' might lie in what the autocratic regimes were doing to maintain the status quo. The paradigm of 'authoritarian resilience' (Albrecht and Schlumberger 2004, Heydemann 2007) considers the capacity of authoritarian elites to overcome challenges from other elites and resistance from the general population. Oil-rich MENA regimes have been able to reduce the developing complexity because they are not dependent on popular support to 'pay their way', given the oil and other 'rents' which some enjoy (Hinnebusch 2006, Peters and Moore 2009). Rentier states have been able to neutralize opposition to political repression - or at least achieve acquiescence - by providing a high level of social and economic benefits to their populations, including public-sector employment (Beblawi and Luciani, 1987, Hanieth 2013). This has been true not only for hydrocarbon-rich countries but also for the ones that benefited indirectly from oil and gas revenues in the region (Peters and Moore 2009) and for countries such as Jordan which benefited from non-economic ('strategic') rents and, in some cases, development assistance and remittances. Autocrats have also been skillful and effective at co-opting potentially disruptive forces - aspects of political Islam, for example (Pace and Cavatorta 2012), or elements of civil society organisation (Jamal 2007, Haddad 2012). More subtly, authoritarian regimes have adopted the appearance and rhetoric of democracy (Carothers 2001, Heydemann 2007, Hinebusch 2006) but given up little or none of their control, thereby co-opting or subverting the use of such symbols oppositionally. AlIssiss and Diwan (2016) suggest that values are distorted in favour of the status quo by governments presenting themselves as the only alternative to outright Islamism. Welzel and Kirsch (2017) demonstrate that authoritarian notions of democracy are real in the sense of not being based simply on fear, but their account is also compatible with discursive manipulation on the part of the state, and Norris (2011) points to the role of information control and oppression of the media. Finally, the autocratic regimes have built up a powerful security sector (Bellin 2004). Regimes have had the support of their armies and police services and have been accustomed to the option of putting down dissent by force.

A further line of explanation has been 'cultural exceptionalism'- that there is something in the culture, history and/or religion of Arab countries that prevents democratic values taking root and flourishing (see e.g. Huntingdon 1993, Lewis 1990). A major target here has been Islam, seen as incompatible with democratic government and the Rule of (non-religious) Law. However, Islam is not a monolithic unity with respect to either the Shari'a or Democracy. Much depends on what is meant by 'democracy' - whether it means a 'liberal' democracy which includes considerations of social justice or a thinner and more procedural variety concerned only with the mechanics of selecting governments and perhaps political rights such as freedom of speech and assembly. On the basis of extensive qualitative research in Egypt, Gillian Kennedy (2017) identifies three varieties of political Islam: - 'moderates' who participate in the political process, 'traditionalists' who tend to reject them, but also a growing 'progressive' tendency which wants to shift the discourse towards socio-economic rights and rights for women and non-Muslims while also seeking a form of democracy compatible with Islamic cultural values. The third of these is seen as a relatively recent development that appears to be attracting young people. The extent to which the Shari'a may be reinterpreted in the light of current circumstances is also of importance - see e.g. Esposito (2003). 
Certainly, Islam has demonstrated in the past that it is not necessarily incompatible with democratic forms of government, in Turkey and Malaysia (Kedourie 1992), Indonesia, Senegal and India (Stepan and Linz 2013) and in Muslim populations in eastern Europe. There is not much evidence to link religiosity as such with opposition to political change (Tessler 2002), and Arab Islamic parties managed to come forward and work together within a democratic framework in both Egypt and Tunisia after the Uprisings. Stepan and Linz (2013), however, argue that a significant degree of institutional separation between religion and the state is necessary for democracy to flourish and that this did not yet exist in the Arab world. Currently it tends to be argued that modernisation is pathdependent and that the broad cultural heritage of a society leaves an imprint of traditional values that endure despite modernisation and retard the transition to liberal democracy (Inglehart and Baker 2000, Inglehart and Norris 2003, Inglehart 2017).

\section{The importance of youth in the Uprisings}

Young people are often seen as key to social and political change (Cole 2014)., and the Arab Uprisings have been portrayed as a movement of youth (Abdalla 2016; Cole 2014; Khouri and Lopez 2011). It has been argued that change comes about not so much by modification of established attitudes as by intergenerational replacement. Younger generations, brought up in changed material and discursive circumstances, in which the values necessary for mere survival are less essential, are where we should find the development of secular and liberal values and the demand for corresponding changes in governance (Inglehart and Welzel 2010, Inglehart 2017). A gradual shift as younger birth cohorts replace older ones should establish the probabilistic paths which, even if not deterministically linear, would lead from authoritarianism to democracy (Inglehart and Welzel 2010).

Young people involved in the Uprisings are reported to have been more educated and urban and less religious than the non-protestors (Cole 2014) and consequently more liberal in their attitudes and more supportive of secular politics and democratisation (Gardiner 2011, Esposito 2011); extended educational provision is among the social mechanisms listed by Lipset (1959) as prerequisite for the sustainable establishment of democratic regimes. Precisely what value changes have occurred, however, is confused in the research literature. Cole (2014) and Momani (2015) argue that youth are pushing for change and are more competitive, accountable and cosmopolitan than previous generations; they want democracy but also hold strongly to religious belief - political Islam (which is not to be confused with Islamist extremism). Moaddel (2017), analysing a 2011 survey conducted in Egypt, hypothesised that age would be one of the predictors of participation in the Uprising because those who grew up in a regime would have more emotional investment in it than those of previous generations, and being of the generation who spent their formative years under Mubarak was indeed significantly related to likelihood of participation, but not to the same extent as being male or living in an urban environment. Shediac et al (2013) find the Arab generations more united than divided, but young people are more concerned with socioeconomic factors than value-based ones. Tessler and Miller-Gonzalez (2016) argue that it is not so much that youth have unique grievances, but rather that they are more prepared to protest because they feel the grievances more intensely and because they are familiar with the use of 'social media'.

A major factor in any explanation has to be that the states of North Africa and the Middle East have failed to provide decent work for their educated young people. On the contrary, the number of jobs in 
the public sector fell, in line with the 'structural adjustment' pressed on MENA countries by development partners and international finance regulators. While state enterprises were privatized, this did not generate opportunities for decent employment. Youth unemployment rates ran high and some, particularly young women, never did make the transition from school to work, failing to join the Labour Force altogether. What work there was available tended to be precarious and to be located in the informal sector (author reference). Where unemployment runs high among young people the outcome at the national level is often turmoil, and this is what happened in the MENA region (Campante and Chor 2012; Hamanaka 2016; LaGraffe 2012).

\section{Changes over time}

Although comparing cross-sectional samples form different periods is not as reliable as longitudinal comparison, both the Arab Barometer and the World Values Survey allow us to make some assessment of the difference between age cohorts and the extent of changes over time:

- Analysis of Arab Barometer II responses for Tunisia and Algeria, just before the Uprisings, found age and gender difference (Tessler and Miller-Gonzalez 2016). They found in both countries that younger people were less personally religious than older people and less interested in politics.

- Analysis of the $6^{\text {th }}$ Wave of the World Values (WVS) and Arab Barometer III, both carried out in Egypt in 2013, however, found little support for intergenerational differences (Elkelani 2016).

- Indeed, comparison of the $6^{\text {th }}$ Wave of the WVS with the $4^{\text {th }}(2001)$ and $5^{\text {th }}(2008)$ found a shift away from post-industrial values by all age groups, especially after 2011. Youth (16-30) did display more post-materialist values than older cohorts in 2000; however, by 2013 intergenerational differences were negligible. On other political values, intergenerational differences were negligible in 2013, with young people now showing an interest comparable to that of older cohorts. Those that were better off, the more educated and those living in urban areas disproportionately supported postmaterialist values, across the generations.

- Analysis of WVS wave 6 data (2011-13) for Morocco, Tunisia, Jordan, Egypt, Iraq and Libya found no differences between younger cohorts and older ones in attitudes to democracy but did find that the younger generation were significantly more individualistic and more favourable to gender equality in all the countries except Libya (Inglehart 2017, Moaddel and de Jong 2017).

- There were also age differences in acceptance of a secular basis for governance, but these were statistical significant only in Lebanon and Tunisia among the MENA countries (Moaddel and de Jong 2017).

\section{ARAB TRANSFORMATIONS SURVEY FINDINGS}

\section{The Arab Transformations Survey}

This paper explores the part young people played in the uprisings, their goals, their attitudes and the extent to which they differed from older age cohortss. The Arab Transformations survey covered adults (18+) in Egypt, Iraq, Jordan, Libya, Morocco and Tunisia in 2014, three years after the start of the Arab Uprisings. A common questionnaire was developed for use in all the countries. Some of the 
questions were drawn from the Arab Barometer and the World Values Survey, and others were composed as 'added value' on security, the Arab Uprisings themselves (including extent of support among non-participants), political involvement since the Uprisings and use of social media.

Achieved samples in each country after quality-checking ranged from 1215 to 2145, and samples were selected by a strategy involving elements of cluster sampling, stratification and simple random selection; the details varied a little from country to country, according to local conditions. Interviews were conducted face to face, in the home in most cases but in one country the occasional interview was conducted in a local coffee-shop if the interviewee preferred. Interviewers worked mostly in daylight hours on weekdays, but one country teametg al 2017 did call-backs later in the working day in cases of non-contact,; two have said that they went back in the evenings and one (where the police advised against evening work) that they called back at weekends. Quality checks included supervisor call-backs to check quality of interviewing, central dependency and coding checks and the application of a STATA routine written by Kuriakose and Robbins (2015) to identify and eliminate implausible exact and near-duplicate entries. More details of the methods employed will be found in (author reference).

'Generation' has been defined in many different ways in different papers. In this analysis we have opted for a simple five-part classification by age cohorts $(18-24,25-34,35-44,45-54,55+)$ to maximize the chance of showing variations anywhere along the age range while not committing to any particular theorized account of what constitutes step-functional differences between generations. When coding variables such as 'participation in demonstrations' we have represented them as 'says took part' or 'does not', including missing value cases in the 'not' category; adopting this tactic is likely to under-estimate what is being measured rather than over-estimate it. The average for missing values on these variables is about five per cent across the six countries, but there are more in some countries.

The research questions for this analysis circle around the proposition that the differences between age cohorts in developing countries form a pattern - a 'rising tide' of liberalisation, secularisation and socially inclusive opposition to discrimination. Specifically we look for differences between age cohorts in:-

- Participation in the Uprisings and support for them: (a) the extent to which younger age groups were over-represented as active participants, and their size as a percentage of the whole group that demonstrated; (b) similar statistics for those who say they supported the Uprisings but do not identify themselves as having participated.

- The extent of 'democratic values' among participants and supporters: approval of democracy as a style of governance in the abstract and its current suitability for their country, in practice.

- Secularisation of values: the extent of religiosity and views on the involvement of religious institutions in socio-political practice.

- Liberalisation of values, taking attitudes to gender equality and women's empowerment as a case study.

Following the body of theory covered above, we should expect differences by age in the part actually played in the uprisings, perhaps in their views on democracy and its suitability, and certainly in a shift from religious edict to secular/rational debate and a liberalisation of social attitudes. 


\section{Age Differences in Support for the Arab Uprisings Participants}

In the pooled sample of six countries, as percentages of the total population of participants (defined as those who attended at least one demonstration or protest), the youngest age-group (18-24) accounts for 18 per cent of participants. About a quarter were 35-44, but nearly a third were 25-34; the 45-54 age-group accounts for 14 per cent and the oldest group 8 per cent. In other words, the largest age group on the streets were those aged 25-34, followed by those aged 35-44, and these two groups account for 60 per cent of participants. In average terms about 40 per cent of those on the streets were middle-aged or even elderly, by anyone's definition, and so it would be a mistake to think of these as solely 'youth revolutions'.

However, young people were over-represented as an age group. If age were not an important determinant, the proportion of the age-groups that took part in demonstrations etc. would be the same for all age groups, and it is not. Past surveys suggested that that participants were drawn from all age groups but with the oldest being less likely to take part; participation was highest among younger age groups. The Arab Transformations survey confirms this pattern in the pooled sample: the oldest age group show as significantly less likely to participate and younger age-groups more likely, but even in the oldest age-group nearly ten per cent participated.

However, the pooled analysis is misleading because it conceals considerable differences between countries.

- The Libyan and Tunisian uprisings may fairly be described as substantial popular movements, with respectively 57 per cent and 26 per cent of the total population saying they were participants. In the middle range, Morocco showed around 11 per cent participating. In the other countries we might see the Uprisings as significant but minority movements on the street: 8 per cent in Egypt, 4 per cent in Jordan and 3 per cent in Iraq.

- Again the pooled analysis conceals country differences. There are no significant differences between age groups in Libya, Jordan or Iraq (Figure 1). The statement that young people were disproportionately represented among participants does hold true in Tunisia, Egypt and perhaps Morocco but there are variations in what is to count as 'young' for this purpose. In Morocco and Egypt the 25-34 age group has the highest participation rate but in Tunisia the highest is the 18-24 group; while in Morocco the 18-24 age group has one of the lowest participation rates. In all three the rate for the older age groups is lower but not trivially small.

Figure 1: Participation in the 2011 Uprisings by country and age group (\% of age group) 


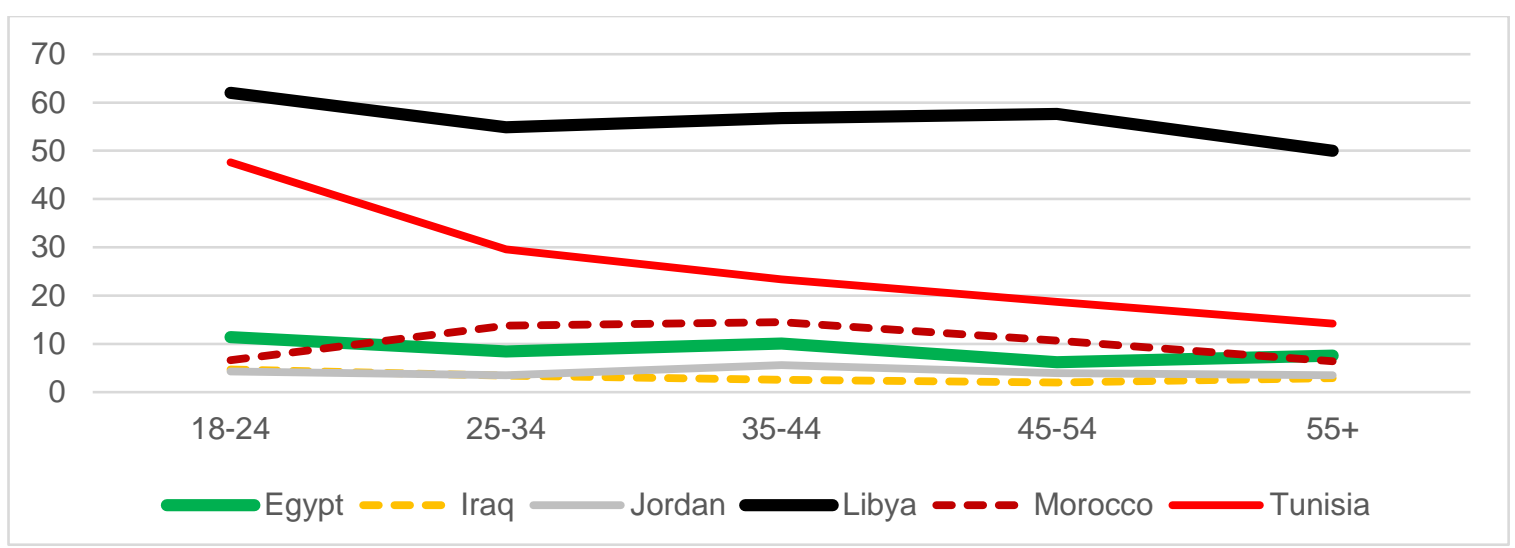

Significance: Morocco 18-24 and 55+ lower than 25-54(p<.001), Tunisia 18-24 higher than 25+ (p<.001), 25-44 higher than 45+ (p<.001), Egypt 18-24 higher than $45+(p<.01), 25-54$ higher than $55+(p<.01)$. No significant differences by age in Iraq, Jordan or Libya.

If we look at the composition of the participant group as a whole (Figure 2) a different pattern emerges. Only in Iraq does the first age group contribute a higher percentage than the second; the second is the high point elsewhere except in Jordan, where the highest is the third. In four of the countries there is a pronounced falling away of participation in the oldest age group, but in Tunisia and Iraq they are slightly more numerous than the preceding age group. Overall, young people played a major role in the uprisings - of those on the streets, people younger than 35 constituted between 61.5 per cent (Libya) and 42 or 37 per cent (Egypt and Jordan). The two oldest groups, aged $45+$, constituted around 20 per cent of those on the streets in three countries (Iraq, Libya and Morocco) and between a quarter and a third in the other three (Egypt 28 per cent, Jordan 32 per cent, Tunisia 25 per cent). Thus there were clearly quite a number of older participants on the streets, but those aged less than 35 dominated in each country, though to different extents and with different contributions from the very youngest group (18-24).

\section{Figure 2: Participation in the 2011 Uprisings by country and age group (\% of those who participated)}

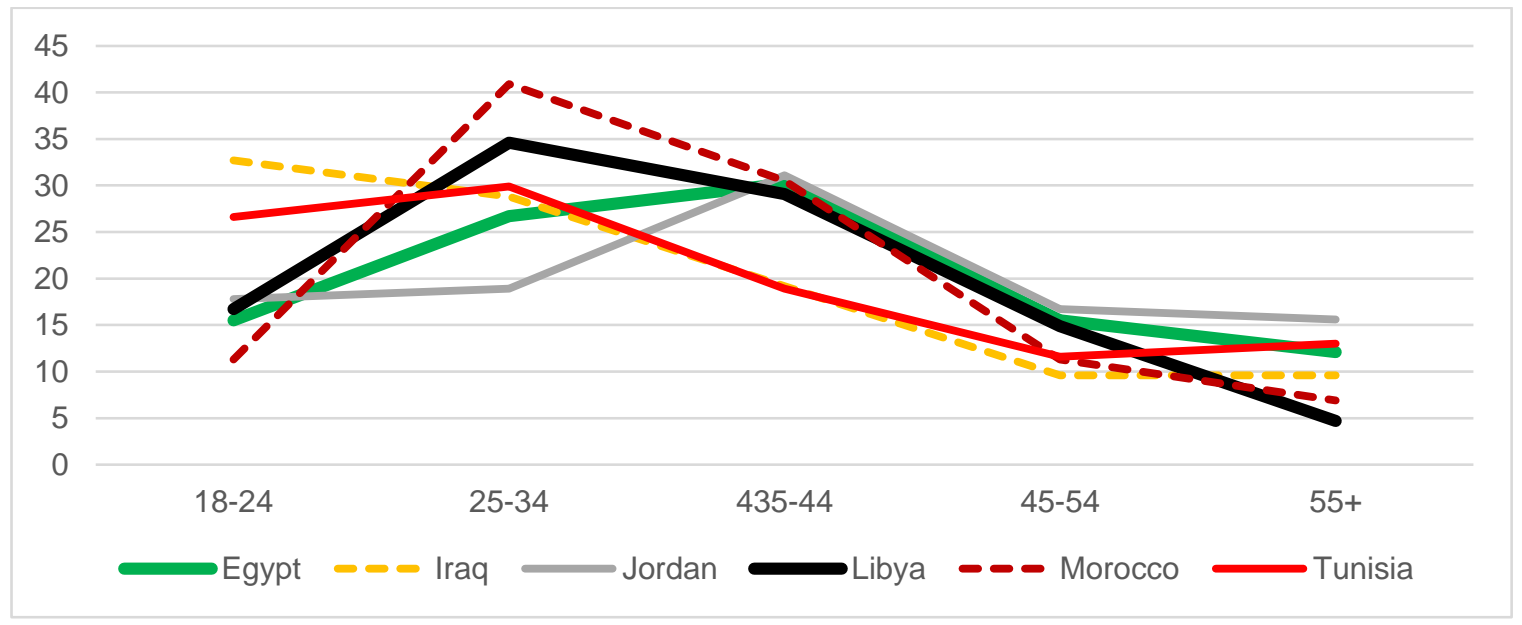

\section{'Armchair' supporters}

The Arab Transformations Survey asked not just who participated in the Uprisings but also who supported the movement. In the pooled sample, 16.7 per cent of all respondents said they were participants, 18.4 per cent were what might be termed 'armchair supporters' (they say they supported but did not actually participate) and 64.8 per cent did neither. (We have added the 3.3 per cent of 
missing value cases in with this third group, on the grounds that they have failed to identify themselves as either participants or supporters.) The validity of the 'armchair supporter' category is open to doubt as a factual report, as it is very easy for 'how I felt in the past' to be reconstructed in memory in the light of current circumstances as 'support 'deep down, in my heart', while a similar process among participants would require them to tell a direct lie to the interviewer. The category remains of interest, however, as an indicator of how they feel now (what they now feel is appropriate) about the revolutionary process. Figure 3 gives the distribution for all three categories by age, in the pooled sample and by country. It will be seen that the average, pooled figure again conceals large variations between countries. Libya and Tunisia stand out from the others, having a relatively smaller proportion who were neither participants nor even passive supporters (less than half) and a relatively large proportion who participated actively - a quarter in Tunisia and over half in Libya. Iraq and Jordan are at the other extreme, with over 80 per cent uninvolved and less than 5 per cent who were active participants. In the other two countries over half were uninvolved, with about 20 per cent armchair supporters and respectively 8 per cent (Egypt) and 11 per cent (Morocco) who were active participants. (For a discission of both ‘*\&*rjsapsford@ gmail.comactibvists' and 'armchair supporters' who were active only or primarilkyh on the internet, see Vincent

Figure 3: Participants, armchair supporters and non-supporters in the pooled sample, by country $(\%)$

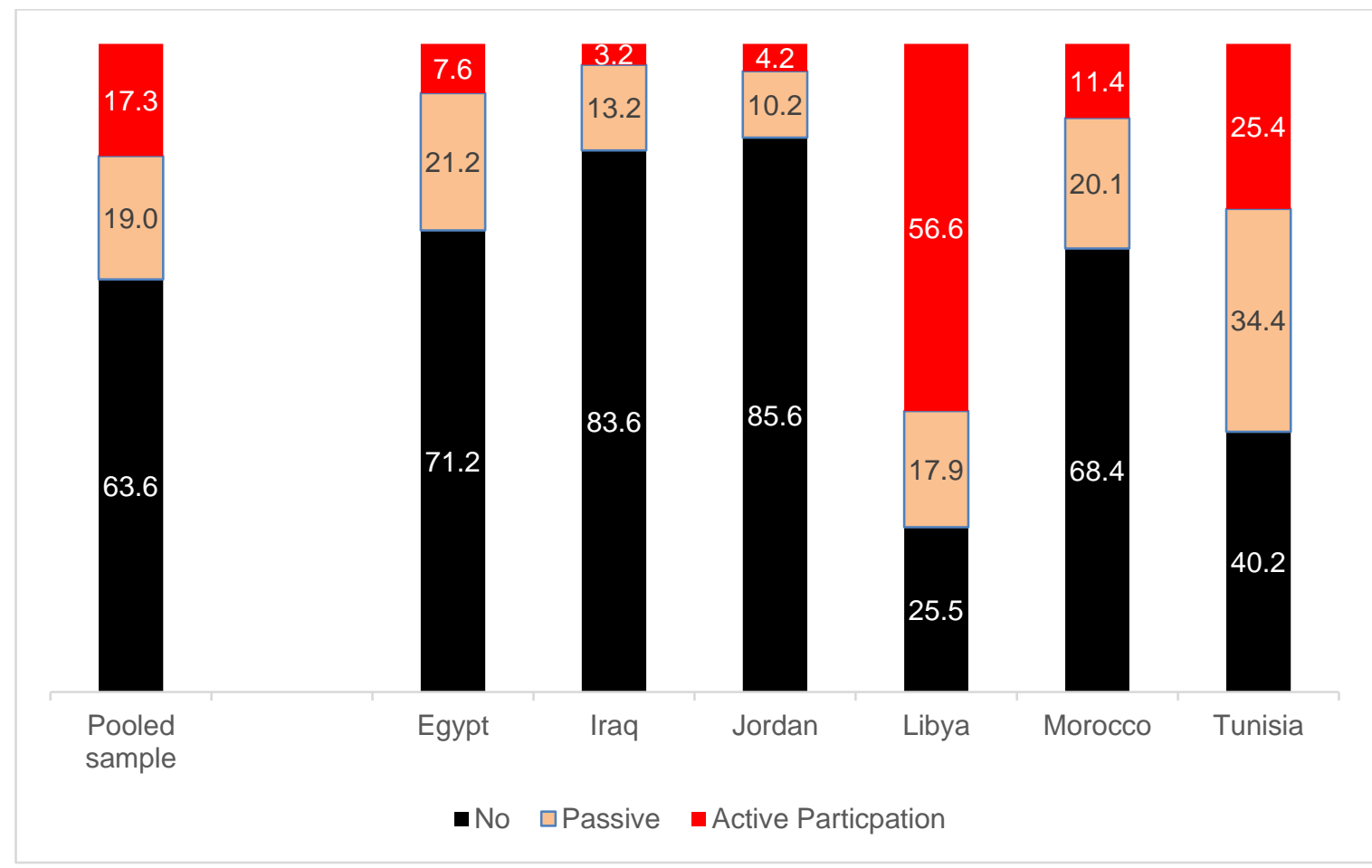

Adding active participants and passive supporters together in the pooled sample (Figure 4), we can see that the total of those in favour of the Uprisings rises a little from the first age-group to the second, then falls away steadily with increasing age. The pattern is due almost entirely to the decline in participation in the higher age-groups of the 'active participants' line; armchair support is more or less a constant across age-groups at round about 18 per cent. 
Figure 4: Participation, support and the sum of the two in the pooled sample (\% of age group)

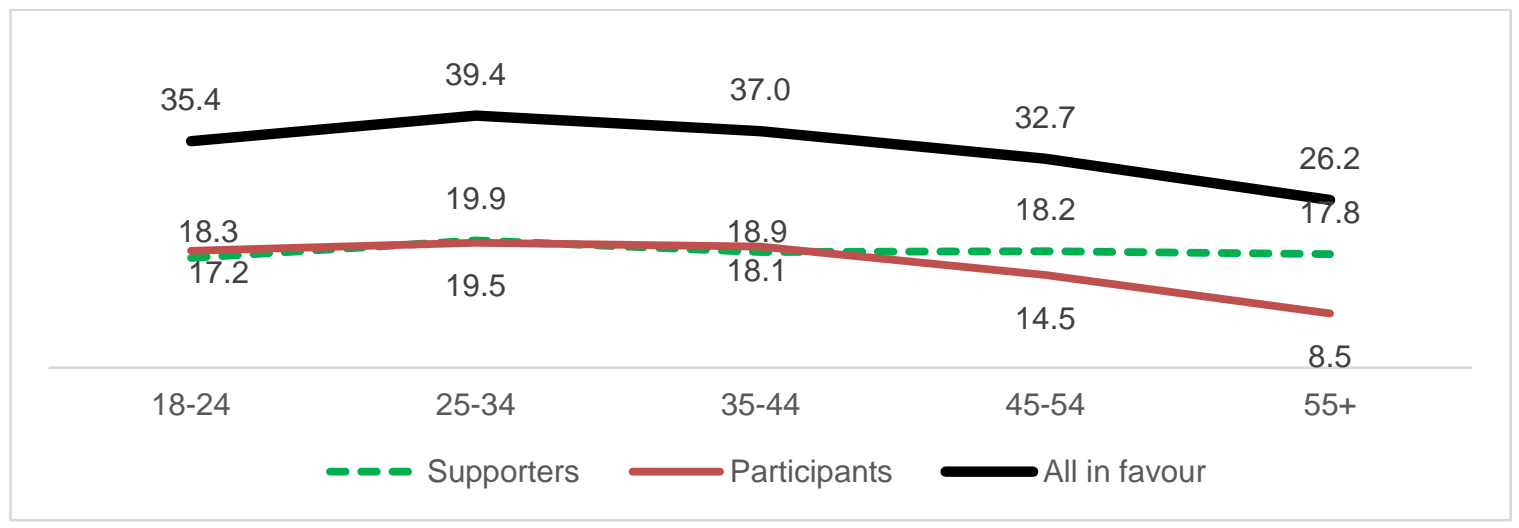

Treating the six countries as one pooled sample again conceals some age variation by country, however (Figure 5). The apparent lack of trend in the 'support' figures conceals opposing trends the gap between supporter and participant numbers widens with age in Jordan, Tunisia and to a lesser extent in Egypt; it narrows or runs parallel in Iraq and, with some irregularities, in Libya and Morocco. In other words, the proportion of armchair supporters is not a constant across all six countries but varies by country.

Figure 5: Participation, support and the sum of the two, by country (\% of age group)

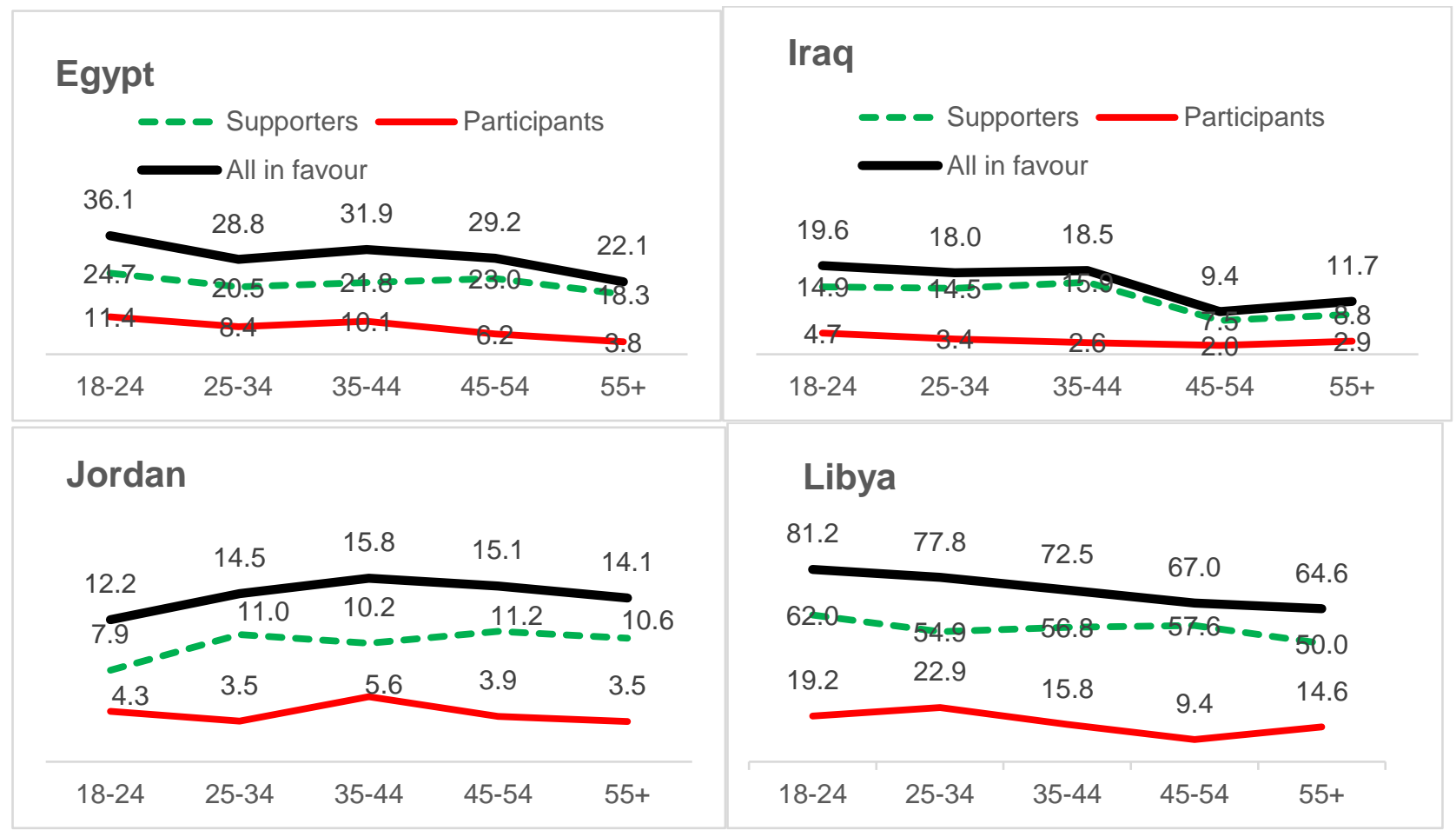



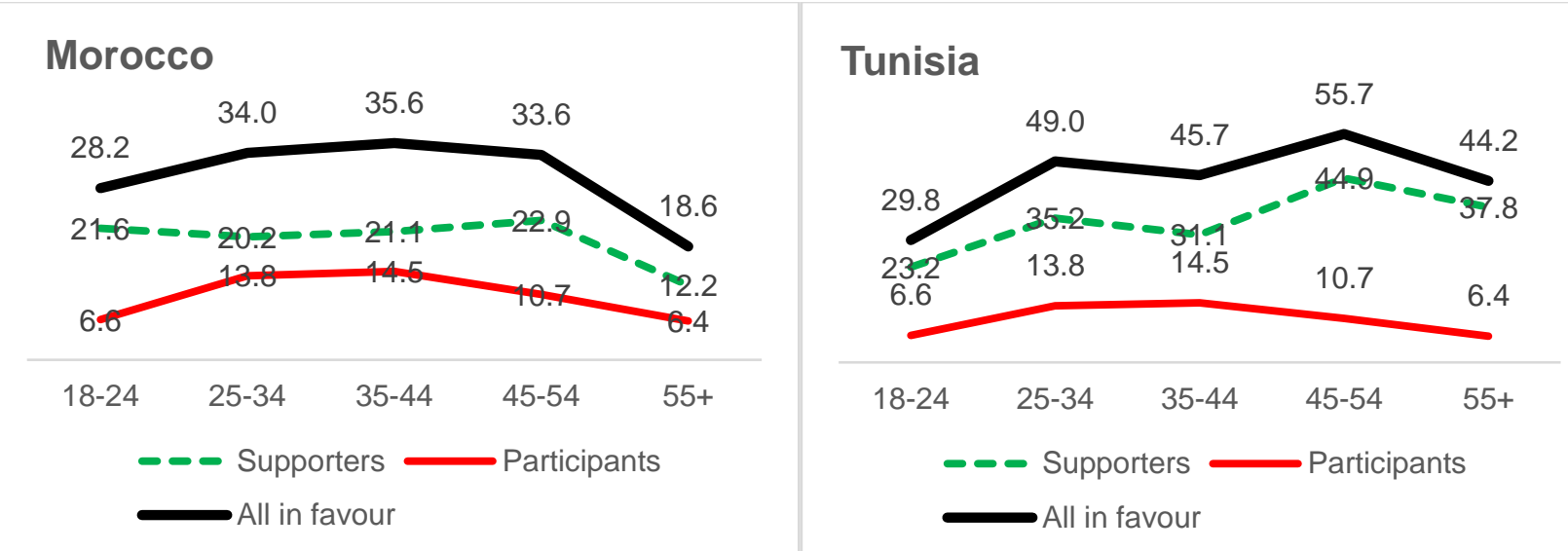

[Set as four rows of two if possible]

\section{Political goals}

When respondents were asked to nominate the two main reasons why people protested in 2011, the most frequently mentioned reason was the economic situation (56.7 per cent), followed by corruption (46.4 per cent), lack of basic services (31.6 per cent), more political freedom (19.7 per cent), to oppose authoritarian leaders (19.7 per cent). and to promote foreign interests ( 9.2 per cent). In other words, 'politics', in the narrower sense of formal electoral systems and 'procedural democracy', was not what people saw as a most important issue. This is not to deny that the uprisings were political, but the most important issues were the economic situation and corruption, nominated by around half of the population, with no other reaching even twenty per cent. There were no significant differences by age for economic problems or promoting foreign interests. (We do not know precisely what respondents meant by the last of these options, which was not elaborated or explained in the questionnaire but merely presented as part of the list to be chosen by those who thought it important.) Age was a significant factor with regard to the otherrjsapsford@gmail.comreasons younger cohorts were more likely than older ones to nominate 'more political freedom', 'oppose authoritarian leaders', 'corruption' and 'lack of basic services' than older people - but the differences were small.

Comparing selection of one or both of the two prime political indicators - political freedom and opposition to autocratic government - with selection of economic situation as important targets, overall 64 per cent named the economic situation and only 37 per cent one or both of the political issues .Jordan stands out because only 23 per cent picked political issues and over 80 per cent named economic issues, and Libya was the only country where more people picked politics (57 per cent) than economic issues (43 per cent). With little difference by country there was a slight tendency for political issues to be named more frequently by younger respondents (from 40 per cent among the $18-24$ s down to 32 per cent in the 55+ group) but little variation by age in whether economics was nominated. Even restricting the analysis to those who participated actively, we find a higher percentage (51 per cent) nominating politics, but 57 per cent nominated economics. The percentage nominating politics is substantially higher in each age group - the pattern does not change - and the percentage nominating economics is a little higher but not more than five percentage points. 
When asked what they saw as the two major challenges facing their countries in 2014 the results were similar. People across the sample were much more likely to nominate the economy (69.1 per cent), corruption (51.6 per cent) and/or the security situation (39.6 per cent) than totalitarianism/authoritarian governance ( 9 per cent), foreign interference ( 7.6 per cent) or even the Palestinian question (3.8 per cent. As well as differences between countries there were also age differences which did not vary much between countries:

- The economic situation: those under 45 are more likely to nominate this as a challenge and those over 55 the least likely, but in individual countries there are no significant differences between younger and older cohorts.

- Corruption: those under 45 (or 35 in Egypt) are the most likely to nominate this and those aged $55+$ the least likely.

- Authoritarian Government: the under-45s are significantly more likely to mention this than older cohorts, but only in Egypt are differences statistically significant.

\section{Differences in democratic values between age cohorts}

Interest in politics is relatively high, with an average across the countries of 73 per cent, varying from a low of 57 per cent in Jordan to a high of 88 per cent in Libya. On the whole, fewer of the youngest age-group voted than the next group (25-34) and the oldest age-group voted least frequently. Just over 60 per cent said that they had voted in the last election, varying from half in Morocco to just over three quarters in Iraq. The youngest age-group is less likely on average to have voted than the second group and voting was also depressed in the 55+ group in four of the countries; Egypt stands out from the others by showing a continuing increase by age, with the highest proportion in the 55+ group, and in Tunisia the proportion voting in the youngest age-group was much lower than in the other countries. As we saw in the last section, political rules and freedoms may be important but economic grievances tend to be prioritised. The latter appear to be of equal interest to all age-groups, but there is a small but discernible trend for younger people to be more concerned than the oldest with political issues.

On the question about democracy being 'the best system despite its faults' - which has been taken by many as the key measure of support for democracy - a strong majority in all countries would appear to be in favour of it. The lowest support is in Egypt (61 per cent), followed by about three quarters in Libya and Tunisia and over 80 per cent in Morocco, Iraq and Jordan. In four countries there is no trend by age, but Egypt shows a decline with age overall and Morocco has a pronounced decline in the final age-group (Figure 6).

\section{Figure 6: 'Democracy is the best system' (\%)}




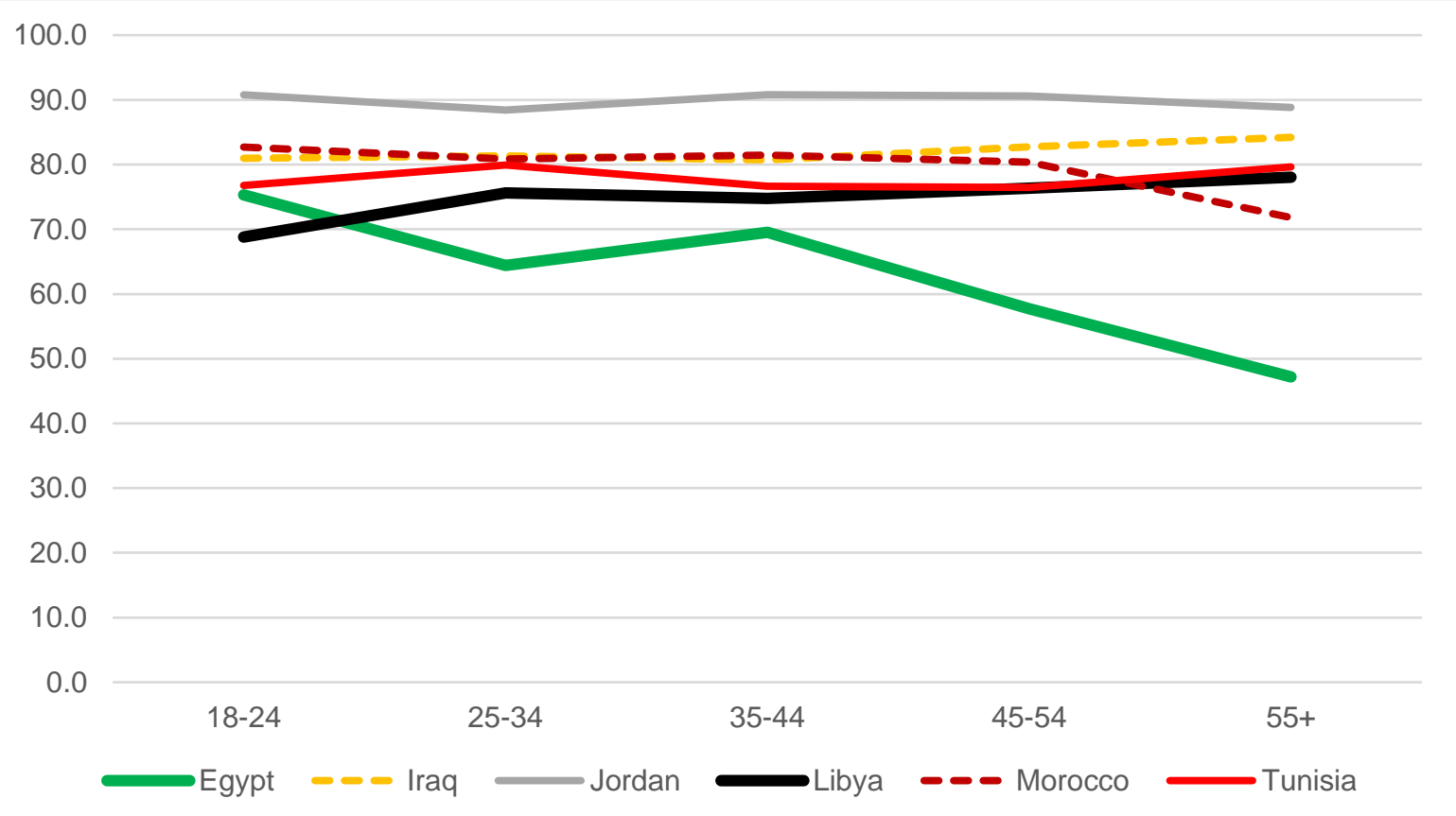

Looking at ratings of democracy's suitability for the respondents' countries, there are no discernible patterns by age but substantial country differences. Only Morocco has a clear majority that consider democracy suitable for their country (Figure 7). Egypt and Iraq have about half and the rest are lower. However, while a third consider it definitely unsuitable in Libya, the remainder range from 21 per cent in Tunisia to 7 per cent in Morocco. It is not clear quite what Arab countries mean by 'democracy' when they praise it as a system or sideline it as unsuitable for them, nor whether they have a shared and coherent understanding of what is meant (de Regt 2013, Welzel and Kirsch 2016, Teti et al 2018). Inglehart and his colleagues (e.g. 2017) argue that it is not a question of measuring a 'desire for democracy, but rather of assessing the extent to which a society has developed the secular/rational and emancipatory/liberal values which are its prerequisites'.

Figure 7: Suitability of democracy for country (\%)

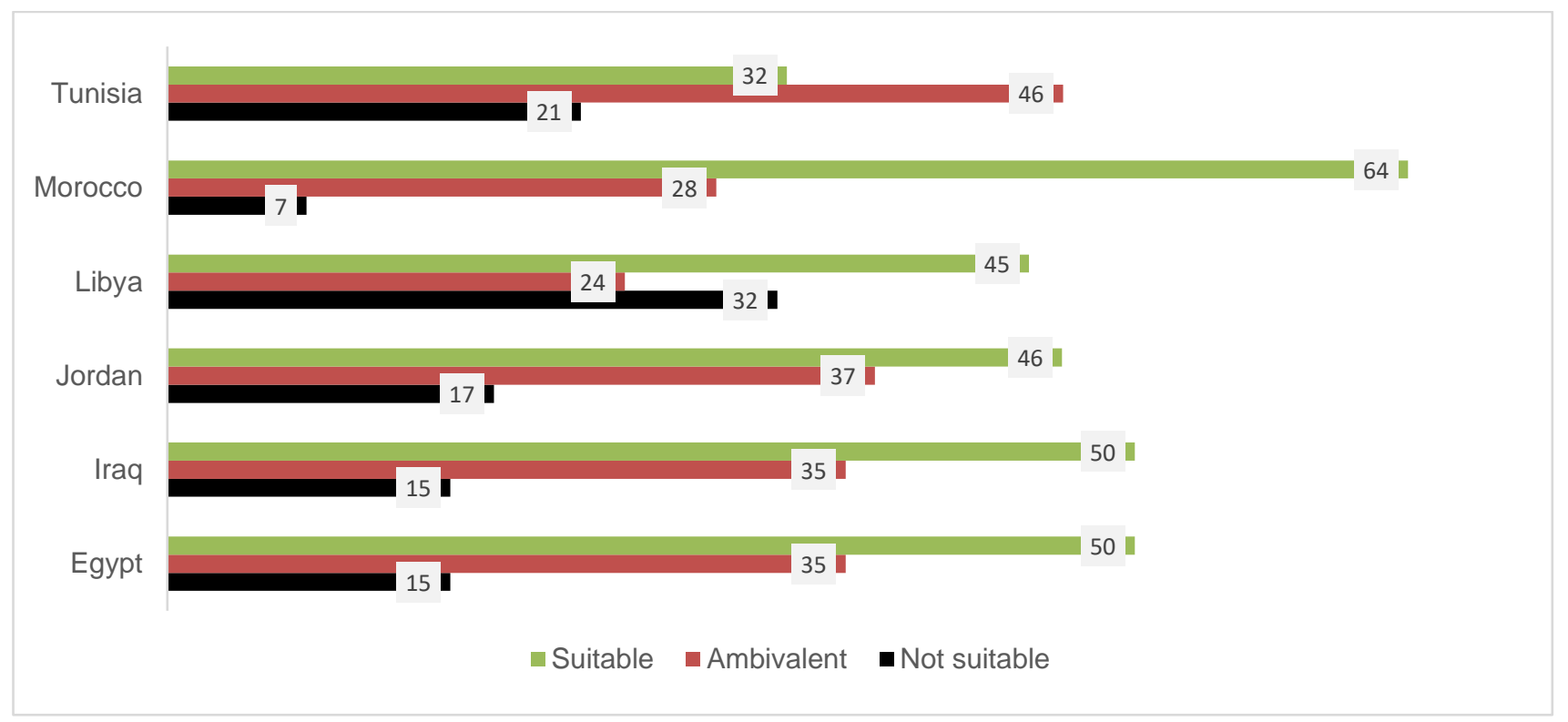




\section{Religion and secularized values}

Like the Arab Barometer, the Arab Transformations survey shows less involvement in religion among the younger age groups than the older ones - fewer young people describe themselves as more than 'somewhat' religious. (Almost no-one in a Muslim country is described as having no religion.) There are large differences between the countries - Egypt and Iraq, at 40-50 per cent, have far more self-described religious people than Libya and Tunisia, at the other end of the scale with respectively 21 per cent and 32 per cent - but the pattern by age is much the same in all countries (Figure 8). There is no trend by age in identifying oneself as a Muslim rather than by nationality, though there are substantial differences by country.

\section{Figure 8: Proportion describing themselves as 'religious', by country and age group}

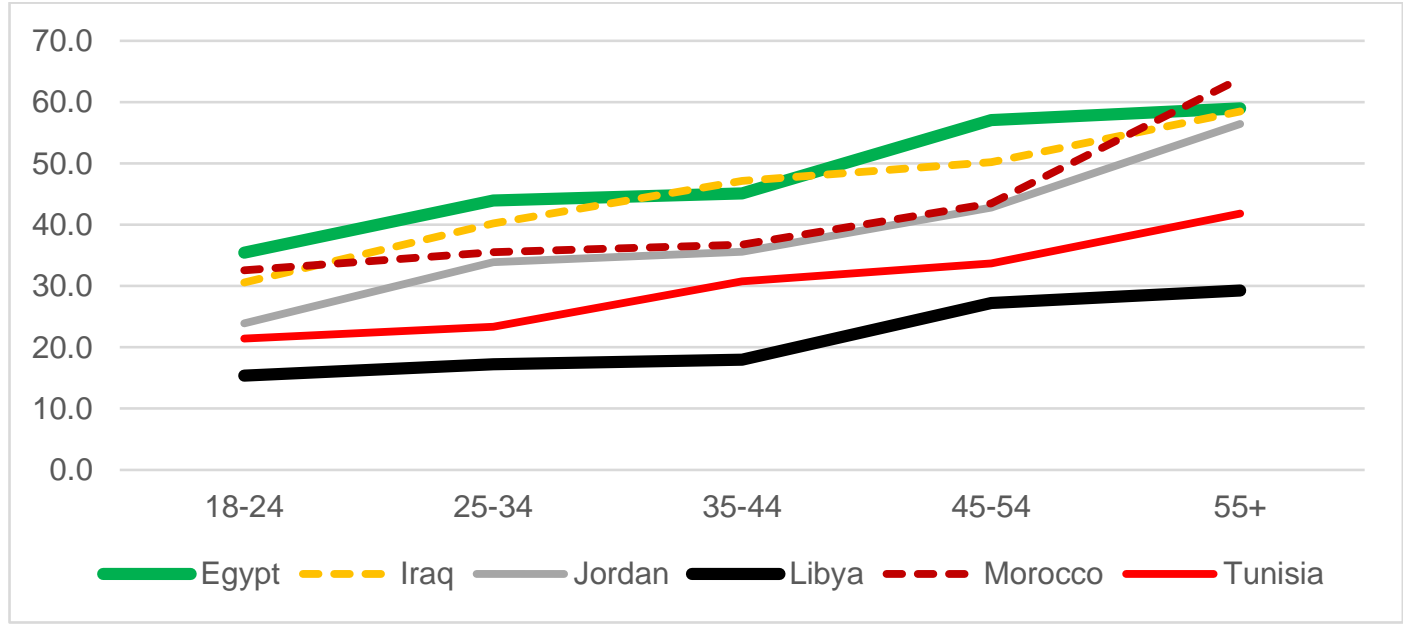

There is also no age trend in markers of secular values - agreeing that religion is a private matter to be kept separate from socioeconomic life, feeling that religious leaders should not meddle with elections nor advise government, preference for a religious party, or even the belief that the shari'a should be the only law - though there are substantial differences by country. Over 80 per cent considered that religious leaders should not attempt to influence elections (over 90 per cent in Egypt and Tunisia, though only 60 per cent in Morocco). Around 75 per cent of Egyptians and Tunisians also considered that they should not be allowed to influence government, and while other country figures are lower, only Iraq falls below 50 per cent. The problem with interpreting these questions on religious leaders and politics, however, is to know which religious leaders respondents mean - the Muslim Brotherhood, al-Azhar, Salafists, leaders at their own place of worship, ... ? - and also why they would trust religious leaders given that in several countries these were generally co-opted by the authoritarian regimes. Nonetheless, Egypt's and Tunisia's score for agreement was also high, over 80 per cent, for the more general proposition that religious observance is a private matter and should be kept separate from socioeconomic life; Iraq and Libya have scores in the 70s, and Jordan and Morocco score below 50 per cent.

The key indicator of secularism in this context is probably the role assigned to the Shari'a in the determination of the country's laws. Any such prioritisation of religious pronouncement over reasoned discussion is not compatible with the Rule of Law as understood in liberal democracies, where laws are in some sense the expression of the will of the people, debated and agreed, and can be changed. Less than eight per cent of the sample as a whole did not want laws based on the Shari'a at all; 48 per cent wanted all law to follow the Shari'a and 44 per cent wanted at least some of it - 
generally family/status law but sometimes criminal law. There are large differences by country in the proportion wanting no Shari'a law at all: in Egypt those who want none of it count for 20 per cent and in Tunisia for 21.5 per cent, while in the other countries they contribute less than 5 per cent and in Jordan less than 1 per cent. Similarly, Tunisia has only 17 per cent who want shari'a as the entire law, but there are 32 per cent in Egypt, around 40 per cent in Iraq and Morocco and around 70 per cent in Jordan and Libya. There is a slight but significant trend by age: those least wanting the shari'a are in the top age-group (55+) and to a lesser extent the next one down (45-54), and those who want only shari'a are higher in the lower age bands. In other words, the trend by age here is, if anything, away from secularisation rather than towards it.

\section{Gender and Politics}

Inglehart (e.g. 2017) has argued that gender is a good indicator of the growth of the emancipatory values which he and his colleagues argue are prerequisite for a stable democracy and that the Arab world is still markedly behind the rest of the world in this respect. In the Arab Transformations survey here are substantial differences by country in answers to the attitude question about men making better political leaders than women: four countries are in the 80 s overall, but Tunisia shows a value of 60 per cent and Morocco, the lowest, has 37 per cent. Decomposition of age trends by country (Figure 9) shows an upward trend in Tunisia and Morocco and perhaps Iraq - young people are more prepared for female leadership - but no significant relationship with age in the other three.

\section{Figure 9: 'Men make better political leaders than women' (\%)}

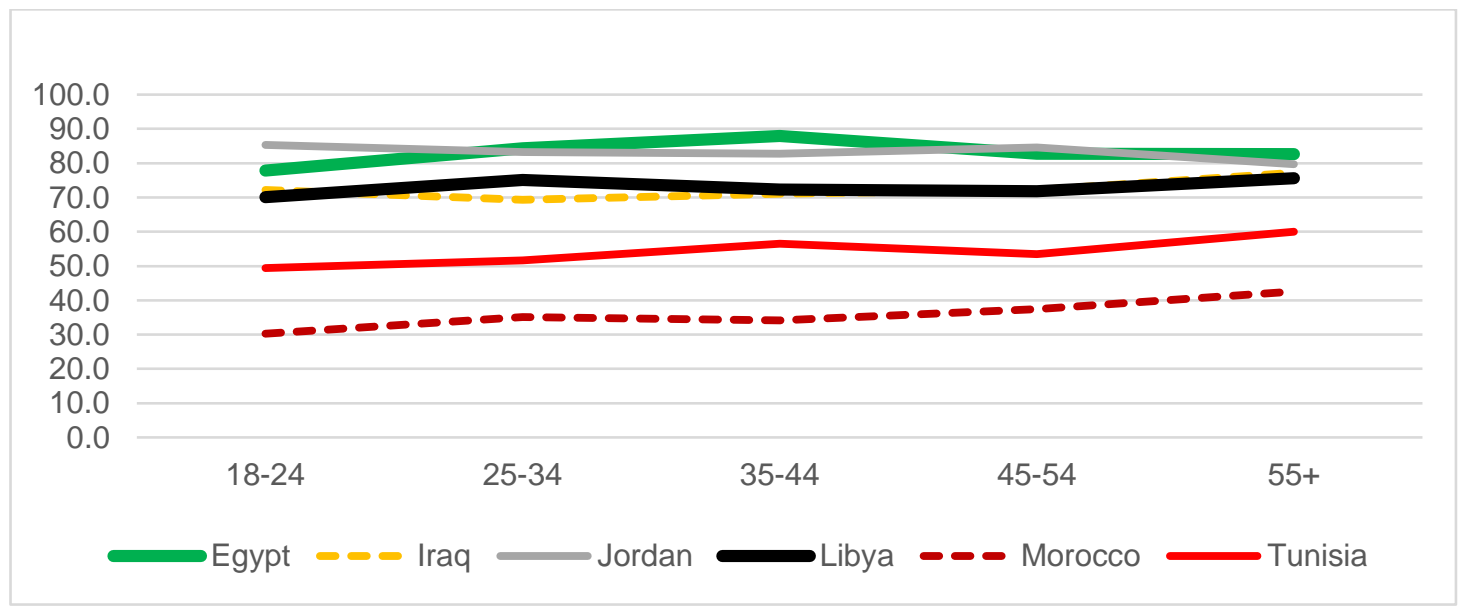

Other useful indicators in this area are whether a woman can be a president or prime minister of a Muslim country, whether women may travel abroad unchaperoned and whether a university place is more important for a boy than a girl. The first two showed a slight increase with age and the third no significant trend. There are quite marked differences by country, however. It is of note that even in the least conservative country on these measures, Tunisia, 19 per cent think a university place is less important for a girl, 27 per cent think a woman cannot be President or Prime Minister in a Muslim country and 38 per cent think women should not travel abroad by themselves. Egypt is also among the lower scorers here.

Acceptance of the shari'a as law - whether family/status law should be based on the Shari'a - is again a useful indicator, interpretable as codifying the 'domestic bargain' of financial support in exchange 
for domestic subservience and underlying the conservative gender stereotyping typical of many Arab countries. In Tunisia 62.5 per cent think that women's status should be determined by Shari'a law and in Egypt 68 per cent; the other four countries score above 85 per cent. There is no trend by age.

\section{DISCUSSION}

Modernisation theory predicted change in the MENA region - replacement of traditional ways of life, given the enhanced complexity and individualism of industrialisation and globalisation, by something more appropriate for the new forms of production and socioeconomic relations. In revisions of the theory, the factors seen as retarding change are attitudinal and organisational; culture and history have to be overcome but are buttressed by sophisticated political and symbolic responses on the part of the ruling elite, backed by crude power and control of the army and police. Signs of impending change were still expected, but mostly among the younger people. The new age cohorts should by now be expected to show signs of changing the balance of attitudes in favour of democracy. This is why the story of youth at the centre of the Uprisings was so important.

This is not what happened, however, because the conditions for it have not been fulfilled. The immediate occasion of the Uprisings, in the view of economists and political scientists, was the series of neoliberal economic revisions forced on the developing MENA countries by the World Bank, the IMF and major aid donors and investors. Under these, governments' control of resources was to be reduced, with large swathes of what had been government-controlled services and production travelling into private hands. The expectation was that this would establish a more independent and forward-moving private sector, generate employment and build economic growth. The economic growth occurred, but not the jobs that it was to have created. Instead, industry was privatized not outside government control but into the hands of 'crony' investors in alliance with government - former elements of the government or people/companies whose interests were in the rewards of insider status more than in generating employment

Nonetheless the picture of young people as politically mobilized and driving the protests does appear at least partly true in some of the countries, though not in others. The Arab Transformations Survey showed that interest in politics tended to decrease with age in Iraq, Egypt and Jordan but increase in Tunisia and Libya; in Morocco the more elevated values were in the middle of the distribution. In terms of practical $\mathrm{p}$ [olitics, countries differ in the proportion who say they would join a demonstrating at the present time (or have already done so) from 8 per cent in Egypt to over half in Libya, but the age distribution varies by country (author reference). Thus there does seem to be some truth in the picture of youth as more politicized than older people but there are different patterns in Egypt and Tunisia than elsewhere, and these are the countries which most caught the attention of the media. The picture of educated young people dominating the revolutionary activities through their access to social media online is also true in parts but misleading overall, according to another report using Arab Transformations data (Vincent et al 2016). The survey appears to confirm that ITC did play a part, offering an uncensored and relatively safe medium for discussion, dissemination of news and organisation of events, but the numbers using these channels are not large enough, particularly in Egypt, for them to be the sole or even the main form of communication among protestors. 
In terms of underlying values, the notion of a rising tide of young people with a lust for democracy and a craving for their human rights is cast into substantial doubt by the fact that liberal political outcomes are not what comes first to respondents' minds as reasons for protesting. The key issues, named by more than half the respondents, were economic grievances and corruption in government. Protest against autocratic government and/or demands for political freedom were named by around 20 per cent overall and there was no consistent difference between age groups. The political issue of authoritarian government was mentioned as a current challenge in 2014 by less than 20 per cent in all countries, and. there were only minor and sporadic differences between cohorts. The issues still seen as challenges in 2014: were economic grievances (jobs, services), corruption and then internal security. This does not mean that political issues were unimportant - a significant minority mentioned them - but they were less important and urgent than corruption and the economic situation.

Looking at the growth of secularism, the extent to which people describe themselves as 'religious', varies by country but the same pattern of increase with age shows in the Arab Transformations Survey as has been found in Arab Barometer and the World Values Survey. However, there are no age trends in the belief that religion should be kept separate from socioeconomic life, the rejection of the right of religious leaders to influence elections or advise governments, or even in the preference for law based on the Shari'a. Further qualitative research is needed, in a wider range of MENA countries, to explore the 'progressive' tendency within Political Islam which Kennedy (2017) finds in Egypt.

Using gender emancipation as a case study of liberalisation, there are some indications that the younger generation considers women in a more equal light than older people, but they are not very marked, and the level of agreement differs between countries (author reference). Asked for their view on whether men make better political leaders than women, fewer in the younger age groups than in the older ones said they believed this in Tunisia, Morocco and perhaps Iraq, and there is something of an upward trend by age in Jordan as well, while Egypt and Morocco show no identifiable age pattern. Over 60 per cent of the total sample felt that family/status issues should be governed by the shari'a, and women were among those who believed this.

\section{CONCLUSION}

Research (and even more the popular media) has portrayed the Arab Uprisings of 2011 as being sparked and led by youth demanding democracy. Middle-class youth, with access to the internet and the relatively new user-friendly social media, are particularly presented as the core of the revolutions. This picture fits some of the information that has been obtained from representative surveys and is interpretable within existing political theory, but taken as a whole it is misleading.

1. While the internet and social media provided a new resource for organisation and mobilisation, outside government control, access to them was limited and we should not overlook the role of already organized civil society bodies, such as the Trade Unions in Tunisia.

2. The picture is mostly based on the findings of qualitative research and journalistic investigation, particularly in the larger cities and particularly with those sufficiently well educated to be interviewed in English or perhaps French. This kind of sampling distorts representation. 
3. However, survey sources - the Arab Transformations Survey and also the Arab Barometer and the World Values Survey - do suggest that a higher proportion of younger people (variously defined) than of their elders were actively involved in the Uprisings and that some degree of secularisation is occurring in the younger cohorts, along with some degree of softening of the discursive discrimination against women.

The real picture is to some extent country-specific. Which younger age group is most likely to have participated and/or to hold the attitudes varies by country. In some it is those aged 18-24, in others 25 34 , sometimes both, sometimes everyone aged less than 45. In some countries and for some aspects of the analysis the age gradient does not emerge at all, or only in the form of a decline among those in their mid-fifties or older. Young people were indeed active in the Arab Uprisings and over-represented in comparison to their size in the population, but more in some countries than others and not necessarily the very youngest age-group. The largest proportion of participants actually come from those in the middle of the age range, even though they are less over-represented in relation to their age group, because the age group itself forms a substantial proportion of the population.

What is clear is that the picture of a 'youth revolution' is something of a myth. The Uprisings were not confined to youth or the middle class and not primarily about human rights and the establishment of formal democracy. Political change was indeed sought and achieved, at least temporarily; two regimes were toppled and replaced by elected presidents and two other rulers had to buy their way out of instability through concessions and subsidies. Politics in the sense of demand for political rights and freedoms was not the only or even the major driving force, however. Where the demand is for democracy, it is clear (see author references) that what is wanted is not just the thin formality of replacing government through free and fair elections, or even the right to criticize government without fear of reprisals, but the decent work and decent lives they see democracies on the other side of the Mediterranean enjoying.

This, at least, is how we interpret the quantitative data. Survey research is strong on representation when properly carried out - it can tell us how many out of the population say they have experienced a given phenomenon or that they support a given position and how groups compare, across and within countries. What it cannot tell us is what they mean by it and what discourses or frames of analysis are being taken for granted as the obvious and right way to approach the nature of social and political life. For this, further qualitative research is now needed.

\section{REFERENCES}

[Six author references have been temporarily deleted to permit anonymous refereeing.]

Abbott P (2017) Gender Equality and MENA: women's empowerment in the aftermath of the Uprisings. University of Aberdeen, Arab Transformations Working Paper 10. SSRN Electronic Journal 2017 (January).

Abbott P and Teti A (2017a) Key Findings from the Arab Transformations Survey. University of Aberdeen, Arab Transformations Working Paper 16. SSRN Electronic Journal 2017 (October). 
Abbott P and Teti A (2017b) A Generation in Waiting for Jobs and Justice: Young People Not in Education Employment or Training in North Africa. University of Aberdeen, Arab Transformations Working Paper 18. SSRN Electronic Journal 2017 (October).

Abbott P, Teti A and Sapsford R (2017) The Myth of the Youth Revolution: The Role of Young People in the 2011 Arab Uprisings. University of Aberdeen. Arab Transformations Working Paper 21. SSRN Electronic Journal 2017 (December).

Abbott P, Wallace C and Sapsford R (2016) The Decent Society: planning for social quality (Abingdon: Routledge).

Abdalla N (2016) Youth movements in the Egyptian transformation: strategies and repertoires of political participation, Mediterranean Politics, 21, pp. 44-63.

Albrecht H and Schlumberger O (2004) 'Waiting for Godot': regime change without democratization in the Middle East, International Political Science Review, 25, pp. 371-392.

Al-Issis, M and Diwan, I (2016) Preference for Democracy in the Arab World, Politics and Governance, 4, pp. 16-26.

Arab Barometer (waves on successive dates): http://www.arabbarometer.org/content/ab-waves

Campante FR and Chor D (2012) Why was the Arab world poised for revolution? Schooling, economic opportunities and the Arab Spring., Journal of Economic Perspectives, 27, pp. 167-187.

Cole J (2014) How the Millennial Generation is Changing the Middle East (New York: Simon and Schuster).

de Regt S (2013) Arabs Want Democracy but what kind? Advances in Applied Sociology, 3, pp. 3746.

Elkelani Z (2016) Intergenerational Value Change in Egypt. (Cairo University, Arab Barometer Working Paper No. 5.) http://www.arabbarometer.org/list-working-papers.

Esposito J (2003) Unholy War: Terror in the Name of Islam (Oxford: Oxford University Press).

Esposito J (2011) Arab youth want democracy, not theocracy. CNN, $28^{\text {th }}$ February.

Gardiner D (2011) Arab youth steps in where Islam failed, Financial Times, $10^{\text {th }}$ July.

Gause G (2011) Why Middle East studies missed the Arab Spring, Foreign Affairs, 90, pp. 81-90.

Hamanaka S (2016) Demographic change and its social and political implications in the Middle East, Asian Journal of Comparative Politics, pp. 1-17.

Hanieth A (2013) Lineages of Revolt: Issues of Contemporary Capitalism in the Middle East (Chicago: Haymarket Books).

Heydemann S (2007) Upgrading authoritarianism in the Arab world. Brookings Institution, Analysis Paper 13. http://www.brookings.edu/,/media/Files/rc/papers/2007/10arabworld/ 10arabworld.pdf.

Hinnebusch R (2006) Authoritarian persistence, democratization theory and the Middle East: An overview and critique, Democratization, 13, pp. 373-395.

Howard, P. and Hussain M. (2011). 'The role of digital media'. Journal of Democracy vol. 22 n. 3, July. 
Inglehart R (2017) Changing values in the Islamic world and the West, in: M. Moaddel and M. Gelfand (Eds), Values and Political Action in the Middle East (New York: Oxford University Press).

Inglehart R and Baker WE (2000) Modernisation, cultural change, and the persistence of traditional values, American Sociological Review, 65, pp. 19-51.

Inglehart R and Norris P (2003) Rising Tide: gender equality and cultural change around the world. (Cambridge: Cambridge University Press).

Inglehart R and Welzel C (2010) What do we know about modernisation today? Foreign Affairs, 88, pp. 33-48.

Issawi C (1956) Economic and Social Foundations of Democracy in the Middle East, International Affairs, 32, pp. 27-42.

Kedourie E (1992) Democracy and Arab Political Culture. (Washington, DC: Washington Institute for Near East Policy).

Kennedy, G (2017) From Independence to Revolution: Egyptian Political Islam and the contest for cultural hegemony (London: Hurst).

Khouri RG and Lopez VM (Eds) (2011) A Generation on the Move: Insights into the Conditions, Aspirations and Activism of Arab Youth. (Beirut: Issam Fares Institute for Public Policy and International Affairs, American University of Beirut).

Knickmeyer E (2011) The Arab World's Youth Army. Foreign Policy, 27 January. http://foreign policy.com/ 2011/01/28/ the-arab-worlds-youth-army/

Kuriakose N and Robbins M (2015) Falsification in Surveys: Detecting Near Duplicate Observations, Arab Barometer Working Paper 2. http://www.arabbarometer.org/content/wp2noble-kuriakose-and-michael-robbins-detecting-near-duplicates-survey-research

LaGraffe D (2012) The youth bulge in Egypt: an intersection of demographics, security and the Arab Spring, Journal of Strategic Security, 5 pp. 65-80.

Lerner D (1958) The Passing of Traditional Society (New York: Free Press).

Moaddel M (2017) The Arab Spring and Egyptian Revolution Makers: predictors of participation, in: M. Moaddel and M. Gelfand (Eds), Values and Political Action in the Middle East (New York: Oxford University Press).

Moaddel M and De Jong M (2017) Youth perceptions and values during the Arab Spring: crossnational variation and trends, in: M. Moaddel and M. Gelfand (Eds), Values and Political Action in the Middle East (New York: Oxford University Press).

Momani B (2015) Arab Dawn: Arab Youth and the Demographic Dividend they will Bring (Toronto: Toronto University Press).

Norris, P. (2011) Democratic Deficits (New York: Cambridge University Press).

Pace M and Cavatorta F (2012) The Arab Uprisings in theoretical perspective: an introduction, Mediterranean Politic, 17, pp. 125-138. 
Robbins M (2017) Youth, religion and democracy after the Arab Uprisings: evidence from the Arab Barometer. The Muslim World, 107, pp. 100-115.

Sapsford R, Tsourapas G and Abbott P (2017) Corruption, Cohesion and the Rule of Law. University of Aberdeen, Arab Transformations Working Paper 15. SSRN Electronic Journal 2017 (May).

Shediac R, Shehadi RT, Bhargava J and Samman H (2013) Generations: Differences and Similarities Across the Arab Generations (New York: Booz and Company).

Shenker J, Chrisafis A, Williams L, Fin T, Tremlett G. and Chulov M (2011) Young Arabs who can't wait to throw off shackles of tradition, The Guardian, $14^{\text {th }}$ February.

Stepan A and Linz JJ (2013) Democratization Theory and the 'Arab Spring', Journal of Democratization, 24, pp. 15-30.

Tessler M (2002) Do Islamic Orientations influence attitudes toward Democracy in the Arab World? Evidence from Egypr, Jordan, Morocco, and Algeria, International Journal of Comparative Sociology, 43, pp. 229-249.

Tessler M (2015) Islam and Politics in the Middle East (Bloomington: Indiana University Press).

Tessler M and Miller-Gonzalez J. (2016) Maghrebi youth in the wake of the Arab Spring: general observations and evidence from Tunisia and Algeria, in: Y.H. Zoubir and G. White (Eds), North African Politics: Change and Continuity (Abingdon: Routledge).

Teti A and Abbott P (2017) After the Arab Uprisings: popular expectations and the EU's response. University of Aberdeen, Arab Transformations Working Paper 3. SSRN Electronic Journal 2017 (January).

Teti A, Abbott P and Cavatorta F (2018) Political, Economic and Social Transformations in the Wake of the Arab Uprisings (London: Palgrave Macmillan).

Vincent K, Sarnelli V, Luguzan C and Waechter N. (2016) Youth and Social Media in Transition. University of Aberdeen, Arab Transformations Project. https://www.researchgate.net/ publication/311722261_The_Arab_Transformations_Project_Youth_and_Social_Media_in_Transit ion

Welzel C and Kirsch H (2017) Democracy misunderstood: authoritarian notions of democracy around the world, World Values Research, 1, pp. 1-29.

Wilson, C., and Dunn A. (2011). Digital media in the Egyptian revolution: descriptive analysis from the Tahrir data set. International Journal of Communication 5.

World Values Survey (waves on successive dates): http://wvs-online.com/wvs.jsp 